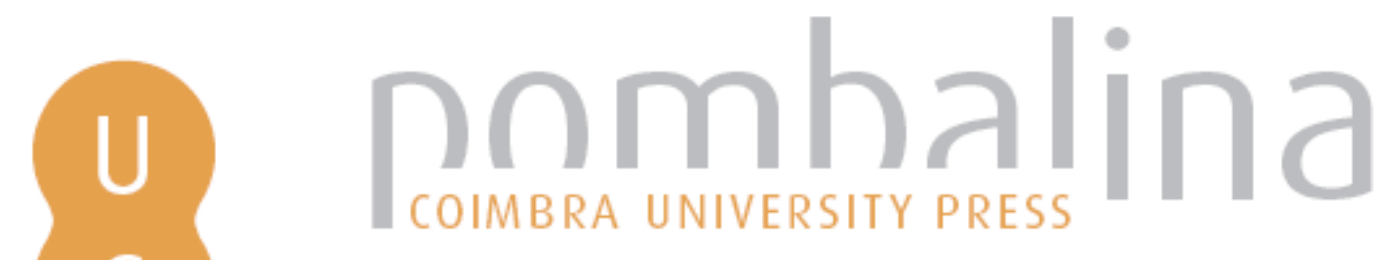

\title{
A comunidade familiar
}

Autor(es): $\quad$ Campos, Diogo Leite de; Campos, Mónica Martínez de

Publicado por: Imprensa da Universidade de Coimbra

URL

persistente:

URI:http://hdl.handle.net/10316.2/38879

DOI:

DOl:http://dx.doi.org/10.14195/978-989-26-1113-6_1

Accessed : $\quad$ 26-Apr-2023 12:28:27

A navegação consulta e descarregamento dos títulos inseridos nas Bibliotecas Digitais UC Digitalis, UC Pombalina e UC Impactum, pressupõem a aceitação plena e sem reservas dos Termos e Condições de Uso destas Bibliotecas Digitais, disponíveis em https://digitalis.uc.pt/pt-pt/termos.

Conforme exposto nos referidos Termos e Condições de Uso, o descarregamento de títulos de acesso restrito requer uma licença válida de autorização devendo o utilizador aceder ao(s) documento(s) a partir de um endereço de IP da instituição detentora da supramencionada licença.

Ao utilizador é apenas permitido o descarregamento para uso pessoal, pelo que o emprego do(s) título(s) descarregado(s) para outro fim, designadamente comercial, carece de autorização do respetivo autor ou editor da obra.

Na medida em que todas as obras da UC Digitalis se encontram protegidas pelo Código do Direito de Autor e Direitos Conexos e demais legislação aplicável, toda a cópia, parcial ou total, deste documento, nos casos em que é legalmente admitida, deverá conter ou fazer-se acompanhar por este aviso. 


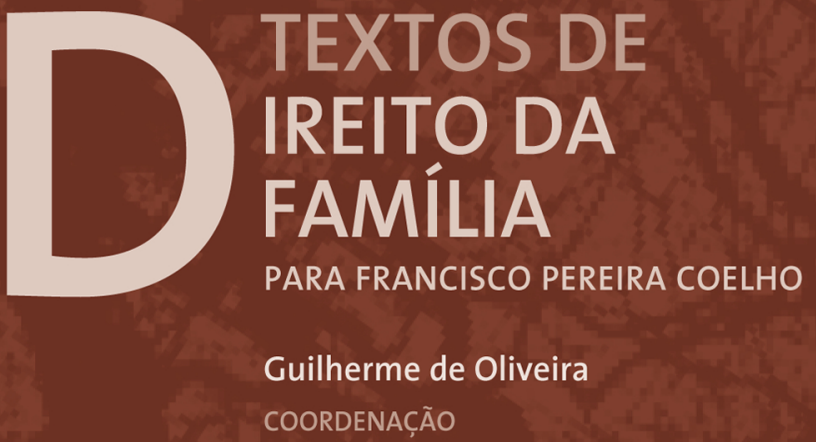




\section{A COMUNIDADE FAMILIAR}

Diogo Leite de Campos Professor Catedrático da Faculdade de Direito de Coimbra (Jubilado) e da Universidade Autónoma de Lisboa

Mónica Martínez de Campos Professora Associada do Departamento de Direito da Universidade Portucalense

\section{A família ${ }^{1}$}

A família em sentido jurídico é integrada pelas pessoas que se encontram ligadas pelo casamento, pelo parentesco, pela afinidade e pela adopção (artigo 1576. ${ }^{\circ}$ do Código Civil). A este âmbito jurídico corresponde um idêntico âmbito social. Embora as relações jurídicas familiares tenham um âmbito mais restrito do que as relações familiares, que se podem estender a primos afastados e a outros parentes. Queremos deixar desde já claro que a família não é em si uma pessoa jurídica, colectiva, portadora de interesses diferentes da comunidade dos seus membros. Quando a lei fala de "bem da família" (artigo 1671. ${ }^{\circ}$ do Código Civil) ou de "interesses morais da família" (artigo 1677. - C, n. ${ }^{\circ} 1$, do Código Civil) está a referir-se ao bem ou aos interesses de todos e de cada um dos seus membros.

${ }^{1}$ Este texto tem como ponto de partida a terceira edição (em elaboração por Mónica Martínez de Campos) das nossas Lições de Direito da Família e das Sucessões, Almedina, Coimbra. 
A família é uma comunidade particularmente propícia à realização pessoal das pessoas, mas não uma identidade diferente destas e muito menos superior ou soberana. A família enquanto comunidade visa o bem de todos e cada um dos indivíduos que a integram.

Se bem que a atribuição de personalidade jurídica à família seja defendida por alguns autores ${ }^{2}$, admitir que a comunidade familiar é uma entidade distinta dos membros que a compõem, sobrepondo-se a eles, que é sujeito de direitos, seria negar a sua existência.

Mas não se pense que o interesse da comunidade familiar levará a que sejam sacrificados os interesses de um ou mais dos seus membros. Não há sacrifício quando a pessoa perspectiva-se no grupo e quando se atende aos interesses de cada um e de todos. Se a família servisse os interesses individuais de cada um dos seus membros, então a atribuição de personalidade jurídica seria uma pura ficção para mascarar uma realidade não-familiar. $\mathrm{O}$ individualismo é, pois, incompatível com a noção de comunidade familiar, e nem pelo artefacto da personalidade jurídica da família se estabeleceria uma família.

\section{A família como entidade social}

O ser humano, sendo ser em si mas também com os outros e para os outros é ser familiar. A família não é uma criação da sociedade e muito menos do direito, mas é ela que segrega, no seu campo específico, um certo tipo de sociedade e um certo tipo de direito. É a família que humaniza o ser humano, que permite a sua sobrevivência, fazendo a ponte para o ser com os outros através

2 Savatier, René, Les métamorphoses économiques et sociales du droit civil d'aujourd’hui, Paris, Dalloz, 1948, pág. 89 e seguintes. Ver também, a proposito da comunidade conjugal e dos regimes de comunhão, a tese de Jean Carbonnier, Le régime Matrimonial, Bordeaux, 1932. 
da demonstração do Amor. O modo de ser específico da família, a sua génese e a sua justificação, estão na capacidade de amor de todos os seus membros, amor que determina uma comunidade de vida. Comunidade bem mais estreita do que a mera comunidade social, também assente em grande parte no Amor mas com este menos presente e muitas vezes menos visível. A vida em conjunto é reconhecida como boa, amada e sobre este amor forma-se uma comunidade de vida. Em que as pessoas são vistas muito para além da sua utilidade, dos serviços que podem prestar aos outros, como valores em si mesmos. Para além do Direito, sempre necessário, a família assenta na primazia do amor e da solidariedade como seu fruto, da misericórdia como a sua última consequência, como fundamento da experiência conjugal e familiar. A família, como grupo global de indivíduos, comunidade ética substancial, é contemporânea da norma jurídica, segregando estas através do amor e solidariedade que constituem a sua razão de ser.

O Amor na família é um constante estar presente, ver, dar-se. Cada um, sendo completamente ele, vê em cada um dos outros o que precisa para ser completamente humano. Tenta ser um com os outros de tal modo os outros se tornam elementos constitutivos do seu ser sem deixarem de ser outros. No início do ser da família está a relação. A relação interpessoal exprime mais completamente na família a estrutura originária do ser. Em que o ser só se realiza no acolhimento do outro. É por isso que na família é particularmente fácil, mas necessário, conjugar todos os verbos em nós. Sendo estranho à família o eu e incompleto o eu-tu. Isto é uma realidade superior à realidade das funções da família. As funções da família derivam do amor solidariedade entre os seus membros. E são animadas por este amor e solidariedade que não permitem que as funções da família possam ser substituídas por outras, dado que em qualidade são, ou são vocacionadas para ser, superiores às funções sociais que nada 
mais serão um seu complemento, se necessário. Passemos à maneira como esta comunidade segrega um Direito que a reconhece e apoia.

\section{A comunhão de vida: os cônjuges}

O casamento, enquanto estado, é uma comunhão plena de vida. Ou seja: é um constante viver de cada cônjuge, não só com o outro, mas para o outro; enriquecendo e afirmando cada uma das pessoas.

Partimos de uma antropologia aberta. Em que o ser humano seja, antes de tudo, auto possessão, irredutível subjectividade; pessoa subsistente em todos os momentos; recusa de objectivação do sujeito, com uma dignidade que recusa qualquer exteriorização ou massificação; ser livre e auto-responsável, determinando os seus fins e os meios para os atingir. Aqui, o sujeito começa a perceber que o afirmar-se é comunicar: o sujeito afirma-se na relação com os outros. Através de uma circularidade ética que, assente na liberdade, é hermenêutica (conhecendo os outros).

O ser estabelece, pois, pontes com os outros. Esta abertura verifica-se ser constitutiva do próprio ser, num círculo de êxodo e regresso a si mesmo que constitui a vida pessoal. A vida de uma pessoa é para os outros: amar, para ser amado; dar, para receber; comunicar para humanizar; transmitir para conhecer. A comunicação, "o ser para", é a própria vida do ser pessoal. Sem comunicação com os outros, a "bumanização" é barbárie. Quando a comunicação se interrompe, sobrevem a morte. O ser para os outros não é um mais que se junta à pessoa humana; é constitutivo desta.

Finalmente, o ser com os outros exprime a realização plena da personalidade através da solidariedade plena com os outros. A comunicação leva a ter uma relação de reciprocidade total que se torna em plena solidariedade. 
A pessoa humana é, assim, sede de valores, unidade vivente de relações inter-subjectivas, de solidariedade constitutiva: perdendo-se, para se reencontrar; dando-se para enriquecer; negando-se, para se afirmar; morrendo para viver.

Vida de cada um, liturgia do amor.

Há quadros da vida humana particularmente adequados para esta solidariedade. Um deles, é o da comunidade familiar.

O matrimónio-comunhão de vida está no oposto do egoísmo. Cada um dos cônjuges dá-se inteiramente ao outro para receber este; dá-se, para receber; quer deixar de ser (só) um para passar a ser dois em um. Fusão impossível. Assim, cada um, ao retirar-se dessa ânsia de fusão sempre renovada, verifica que trouxe o melhor do outro, humanizando-se mais.

Este amor (necessariamente doação) pelo outro, torna cada um aberto a todos os outros. Antes de mais, aos filhos, objectivação da sempre desejada mas impossível fusão. Mas também a todos os outros que cada um dos cônjuges, habituado à comunicação com o outro, está mais disposto e é mais capaz de reconhecer e amar como um outro eu.

É este amor-solidariedade, muitas vezes só amizade-solidariedade, em último caso, dever/solidariedade que anima a comunhão da vida.

Tentou o legislador aprofundar o conceito de comunhão da vida, decompondo-a correctamente entendidos devam estar sempre em diálogo com o amor (em todos os seus graus de realização).

O legislador civil, muito correctamente, ao ocupar-se da comunhão de vida conjugal, específica deveres, não direitos. É certo que a denominação de "direitos" da personalidade é aceitável no plano das relações inter-individuais em geral, nomeadamente na defesa da pessoa contra as organizações mais poderosas como o Estado.

Mas no interior da comunhão de vida, seria inadequado partes de "direito": A quê? A ser amado? A exigir, com pouca eficácia, um comportamento do outro? 
No âmbito da comunhão de vida conjugal o primeiro movimento é "ver" o outro, o dar(-se).

Há que desvalorizar, também nesta matéria, o carácter autoritário do "direito" subjectivo. A família é animada por imperativos éticos e sociais, transformados em deveres. E não por uma lógica autoritária de conexões obrigação/direito - coação - sanções. São aqueles imperativos éticos e sociais que organizam e dinamizam a família. Os indivíduos estruturam-se em comunidade com base em referências comuns de carácter ético-social. A sanção vem depois e noutro plano, verificando o incumprimento e reparando o dano ${ }^{3}$.

\section{Dever de coabitação}

O conceito de coabitação em Direito matrimonial, mas também em linguagem vulgar, significa comunhão de leito, de mesa e de habitação.

Segundo o artigo $1673 .^{\circ}$ do Código Civil, os cônjuges devem fixar, de comum acordo, a residência da família. Nesta fixação devem levar-se em conta os interesses de todos os membros da família, de cada um dos cônjuges e dos filhos, não sendo possível descortinar o interesse próprio da família enquanto conjunto. Será atendendo às necessidades de cada um dos membros da família que se poderá chegar a uma composição em termos de fixação de uma residência comum.

\subsection{Dever de Fidelidade}

Os cônjuges têm obrigação de guardar mutuamente fidelidade conjugal. A violação mais grave desta obrigação, traduzida na manutenção de relações sexuais consumadas entre um dos cônjuges e

\footnotetext{
${ }^{3}$ Leite de Campos, Diogo, Relações de associação, o Direito sem direitos, Coimbra, Almedina, 2012.
} 
terceira pessoa, tem o nome de adultério. Contudo, outras violações menos graves do dever de fidelidade, não pressupondo as relações sexuais entre o cônjuge e terceiro, também constituem violação do dever de fidelidade, por se traduzirem numa negação da comunhão de vida em que se traduz o casamento.

\subsection{Cooperação}

A comunhão de vida pressupõe que cada um dos cônjuges esteja permanentemente disponível para dialogar com o outro, auxiliá-lo em todos os aspectos morais e materiais da existência, colaborar na educação dos filhos, etc. Trata-se, ao lado do débito conjugal (o nome inadequado para algo que numa comunhão de vida deve ser, e é, tão espontâneo) de um dos núcleos da comunhão de vida. E também, um dos aspectos mais difíceis de controlar de fora, de

mais difícil apreciação a nível da prova pelo Juiz; isto, quando o divórcio litigioso assentava na culpa ou quando um dos cônjuges pretende ser indemnizado pelos danos sofridos causados pelo não cumprimento do dever de cooperação.

Talvez seja este dever que esteja mais no centro da comunhão de vida. Estendendo-se à assistência e ao respeito, e encontrando as suas raízes próximas no amor.

O amor/solidariedade na família assume radicalmente a característica do dar(-se). Cada um, sem renunciar a si mesmo, mais, sendo completamente e cada vez mais "amorosamente" ele mesmo, vê em cada um dos outros o que precisa para ser completamente. Dá e recebe; ama e é amado; perdoa e é perdoado; disponibiliza-se e vive em comunhão; tenta, de tal maneira, ser um com os outros, que os outros se tornam elementos constitutivos do seu ser sem deixarem de ser outro.

É na família que cada um primeiro se apercebe da sua incompletude e se humaniza no intercâmbio constante com os outros. Completando-se. Ninguém existe sem os outros. 
Na família cada um descobre que o eu é os outros, os outros fazem parte do eu.

$\mathrm{Na}$ família (re)descobre-se o amor (como doação original, como vida encarnada na Vida).

Os humanos recebem antes de dar, no ventre da mãe, nos primeiros anos da vida familiar, na aprendizagem. Os seus primeiros actos de amor são pedir e receber. No início está a relação. O Tu é inato. A relação interpessoal exprime a estrutura originária do ser. Em que o ser só se realiza no acolhimento do outro.

O ser não é, pois, alteridade inalcançável, mas êxodo imanente. O Eu-Tu(-Eles) são "palavras-base" expressivas de realidade. Não são palavras isoladas, mas um casal de termos, recolhendo a realidade como encontro ${ }^{4}$.

Quando um ser humano diz ao outro: amo-te para sempre, significa que precisa do outro radicalmente. Prometendo dar-se completamente para receber o outro até serem um só (sem deixarem de ser dois).

Nunca conseguindo ou sequer querendo ser totalmente um, nunca sendo uma só carne (uma só carne significa, uma só realidade, corpo e espírito), tentam unificar os seus seres e o seu amor nos filhos. Amando-se um ao outro nos filhos, dando-se um ao outro na recriação de si mesmos - outros, ao reconhecerem os filhos como bons.

Daqui que a procriação esteja naturalmente presente no casamento como um dos seus elementos constitutivos 5 . Amar só um ao outro, pode ter um sabor de incompletude se não existirem filhos, se os filhos foram afastados deliberadamente. Esta incompletude

\footnotetext{
${ }^{4}$ Buber, Martin, Eu e Tu, trad. N. A Von Zuben, S. Paulo-S.P., Cortez \& Moraes, 1977.

5 Contra, Castro Mendes ("Família e casamento" in Estudos sobre a Constituição, vol. I, 1977, p. 372) e Antunes Varela, (Código Civil anotado, vol. V, p. 622) para quem o direito de celebrar casamento e o direito de constituir família (artigo 36 $\mathrm{n}^{\circ} 1$ da CRP) reduzem-se a um só direito, o de casar. A constituição da família seria um efeito deste direito.
} 
deveria ser A razão, e não uma das razões, que levaria os casais que não podem, naturalmente ou com recurso às actuais técnicas de procriação conceber um filho, a adoptar. As relações de adopção, à semelhança da filiação natural, estabelecem-se entre o ou os cônjuges (adoptantes) e o adoptado (artigo $15860^{\circ}$ do Código Civil). E tanto a filiação natural como a adoptiva são relações de afectos. Só é pai aquele que se relaciona com o filho. Tanto é que a legitimidade do poder-dever dos pais em relação aos filhos, as responsabilidades parentais $^{6}$, assenta no amor.

A partir da concepção/criação dos filhos e durante a sua vida, cada um dos cônjuges revive a vida do outro desde o início, desde a concepção, sendo um com ele desde a concepção, unificando-se e revivendo na memória. As duas vidas conhecem-se e unem-se na sua totalidade. Superando a ardente aspiração de amor de Santo Agostinho por Deus: "Tarde te amei, Beleza tão antiga como nova. Tarde te amei"7, os cônjuges amam-se desde o início.

Poderia dizer, neste momento, que o amor significa fidelidade, que o amor significa constância, disponibilidade e doação. Os esquimós têm quarenta e nove nomes para designar o gelo, em todos os seus estados, aspectos e utilidades. Os nomes para designar o amor dentro da família são tantos quanto os actos da vida quotidiana ou os estados de espírito.

A pessoa, para ser, edifica uma comunidade de próximos e reencontra-se nos outros, na universalidade da pessoa. Existe, comunicando.

\footnotetext{
${ }^{6}$ A Lei 61/2008 substituiu a terminologia "poder paternal" por "responsabilidades parentais". Assim, para Clara Sottomayor, in Temas de Direito das Crianças, Almedina 2014, pág. 50: "Na relação com os pais, a criança deixa de estar sujeita ao poder paternal, como um conjunto de direitos-deveres, em que a componente dos direitos era acentuada, para ser uma pessoa numa posição de igual dignidade à dos pais, pela qual estes assumem responsabilidades e deveres de cuidado e de educação, respeitando as suas aptidões físicas e intelectuais, assim como os seus afectos".

7 Confissões (X, 27, 38).
} 
E é neste momento que a pessoa é particularmente intensa no âmbito da família, leva à natural comunidade de dois ou mais seres. Ao dar-se para receber, ao ser co-autor de todos os outros e obra de todos os outros, cada membro da família vai-se transformando e amoldando ao conjunto em sucessivos actos de amor.

Para se chegar à totalidade do amor, há que reconhecer, antes, o outro. É preciso que o eu esteja em relação com o outro que me cria e me põe em causa. $\mathrm{O}$ outro não pode ser reduzido ao mesmo. Só o acolhimento do outro, na sua diversidade irredutível, constrói o ser e abre caminho ao amor que é alteridade, não domínio.

\subsection{Dever de Assistência}

O dever de assistência, ao contrário do dever de cooperação, tem carácter marcadamente económico: compreende a prestação de alimentos e a contribuição para os encargos da vida familiar (artigo 1675. ${ }^{\circ}$, 1 , do Código Civil).

Este dever bifacetado incumbe a ambos os cônjuges, nos mesmos termos, de harmonia com as possibilidades de cada um. Pode, porém, ser cumprido por qualquer deles, se o outro não quiser ou não estiver em condições de o fazer. No caso de um dos cônjuges não cumprir o seu dever de assistência, resultam daqui duas consequências principais:

Mais uma vez aqui será difícil precisar mais, pois tudo dependerá da situação concreta. E, mais uma vez aqui, se nota a dificuldade da penetração do Juiz nesta matéria, salvo em casos de violação, extremamente graves, deste dever. Difícil será apreciar a medida em que um dos cônjuges poderia cumprir o seu dever de assistência e a medida das necessidades dos outros.

O dever de assistência compreende, não só o necessário para que os restantes membros da família se alimentem, se vistam e abriguem e satisfaçam as suas necessidades de educação, como também o necessário para as actividades culturais, desportivas e de lazer deles. 
Tudo isto atendendo aos hábitos correntes no meio social da família, e às efectivas possibilidades económicas do obrigado.

Isto, sem prejuízo de uma planificação da vida económica da família, que leva, em algumas circunstâncias, a sacrificar despesas de consumo, por muito legítimas que estas sejam, em benefício de despesas de investimento. Assim, se um dos cônjuges decidir comprar uma casa como investimento, com os seus bens próprios, isto poderá levar a sacrificar legitimamente uma parte das férias, certas despesas com vestuário, etc.

\subsection{Dever de Respeito}

O dever de respeito é fundamentalmente o dever de aceitar o outro cônjuge como a pessoa que ele é.

No momento em que os cônjuges se casaram, celebraram um contrato com uma certa outra pessoa, com os seus defeitos, as suas virtudes, etc. Será esta pessoa que eles terão de aceitar, de respeitar, no decurso da sua vida conjugal.

Enunciado este princípio geral, em si pouco significativo, haverá que the introduzir precisões.

Existe aqui uma tensão entre dois interesses. Por um lado, o interesse de cada um dos cônjuges a ser, e a continuar a ser, aquilo que era. Por outro lado, a necessidade de cada um dos cônjuges se adaptar àquilo que o outro é, ou venha a ser. Assim, cada um dos cônjuges poderá ter, e manter, as suas opções ideológicas, religiosas, a sua actividade profissional, política, social, o seu círculo de amigos, os seus hábitos pessoais, sem que o outro cônjuge deva interferir neles. Mas deverá também, de algum modo contraditoriamente, adaptar, conformar ou restringir os seus hábitos, a sua maneira de pensar, de maneira a não ferir os sentimentos do cônjuge. A comunhão de vida, é isto mesmo: cada um dos cônjuges, sendo o que é, adapta-se àquilo que o outro é, numa interacção mútua, de maneira a passarem a constituir uma unidade, esta completa, enquanto cada uma das metades era incompleta. 
Queremos chamar a atenção para mais dois pontos. Um deles, é o facto de a maior proximidade dos cônjuges no seio da família, levar a que cada um deles deva ser particularmente respeitoso, particularmente cuidadoso, da personalidade do outro. Na medida em que está em condições de mais facilmente ofender os seus direitos ou perturbar a realização pessoal do outro.

O outro aspecto a salientar é o seguinte.

O natural desejo de felicidade dos cônjuges deve ser temperado pela sua responsabilidade. É difícil, a prática tem-no demonstrado, contrariar a vontade expressa por um dos cônjuges no sentido de divorciar8. Mas, só causas graves deveriam levar ao divórcio, tais como a ruptura definitiva do casamento (artigo $781 .^{\circ}$ al. d) do Código Civil).

\section{Comunidade familiar patrimonial}

A comunhão de vida, que é o casamento enquanto estado, deve existir no duplo plano pessoal e patrimonial. A disponibilidade de

\footnotetext{
8 Veja-se, a título de exemplo, o sumário do acórdão do STJ, de 09/02/2012 (Processo 819/09.7TMPRT.P1.S1 in www.dgsi.pt), onde se pode ler:

"I - A adesão ao conceito-modelo do "divórcio-constatação da ruptura conjugal" representa uma nova realidade destinada a ser o instrumento para a obtenção da felicidade de ambos os cônjuges, conduzindo à concepção do divórcio unilateral e potestativo, em que qualquer um dos cônjuges pode pôr termo ao casamento, com fundamento mínimo na existência de factos que, independentemente da culpa dos cônjuges, mostrem a ruptura definitiva do matrimónio, por simples declaração singular, ainda que a responsabilidade pela falência do casamento lhe possa ser imputada, em exclusivo ...

V - A família transforma-se num espaço privado, de exercício da liberdade própria de cada um dos seus membros, na prossecução da sua felicidade pessoal, livremente, entendida e obtida, deixando o casamento de assumir, progressivamente, um carácter institucional, maxime, sacramental, sobretudo na componente da afirmação jurídico-estadual da sua perpetuidade e indissolubilidade, para passar a constituir uma simples associação de duas pessoas, que buscam, através dela, uma e outra, a sua felicidade e realização pessoal, e em que a dissolução jurídica do vínculo matrimonial se verifica quando, independentemente da culpa de qualquer dos cônjuges, se haja já dissolvido de facto, por se haver perdido, definitivamente, e sem esperança de retorno, a possibilidade de vida em comum."
} 
cada um dos cônjuges perante o outro, que é o reflexo do amor e que consubstancia a comunhão de vida, deve ser uma disponibilidade da pessoa e dos bens de cada um dos cônjuges. Mal se compreenderia que houvesse uma comunhão de vida quando cada um dos cônjuges não gozasse como se fossem seus, os bens do outro. Contudo, o aspecto patrimonial nada mais é do que o reflexo do aspecto pessoal. Pode não haver bens, mas havendo pessoas, a comunhão de vida é possível, totalmente. Suponha-se que um jovem casal vive em casa dos pais de um dos cônjuges, sendo alimentado por eles. Neste caso, não havendo interesses patrimoniais dos cônjuges, há, seguramente, ou deve haver, uma completa comunhão pessoal.

É perfeitamente possível imaginar uma completa comunhão de vida entre duas pessoas, tanto no aspecto pessoal como no aspecto patrimonial, mas que não implique entre elas relações jurídicas patrimoniais diferentes daquelas que se estabelecem entre duas pessoas estranhas. Os bens continuarão a pertencer a cada um dos cônjuges; adquiridos serão do seu adquirente, ou então adquiridos em compropriedade; cada um dos cônjuges administrará livremente os seus bens; etc. Parece ser aliás, esta, a situação "natural», na medida em que, sendo a comunhão pessoal a base, a comunhão patrimonial derivará automática e flexivelmente dela. Um perfeito entendimento dos cônjuges transformará qualquer regime de separação de bens em comunhão; enquanto que os desentendimentos dos cônjuges converterão um regime de comunhão numa fonte de conflitos.

Não esquecemos que a comunhão de vida introduz necessariamente nas relações patrimoniais ingredientes que não existiriam entre duas pessoas absolutamente estranhas. É natural que um dos cônjuges, o mais habilitado, se ocupe da administração dos bens do outro; como ambos gozarão, indiscriminadamente, do conjunto dos bens. Contudo, não se nos afigura que estas circunstâncias exijam a criação de um especial estatuto patrimonial das relações entre os cônjuges. Deverão ser consideradas como resultantes necessárias da 
comunhão de vida, sem relevância jurídica autónoma. Quando muito, e para casos de particularmente intensa colaboração económica entre os cônjuges, com resultados muito significativos para um deles, haverá que estatuir expressamente o recurso a algum dos institutos consagrados do direito das obrigações ou dos direitos reais, como o enriquecimento sem causa, as benfeitorias, etc.

É a ingerência do direito nas relações patrimoniais entre cônjuges que pode levar a sentimentos de posse, transformando o eu em nós num eu em si, os deveres familiares em direitos do indivíduo, a comunidade familiar numa colectividade. Ou seja, o dever ser com o outro no direito a ser e a ter contra o outro. O que mais se coaduna com a comunidade familiar patrimonial ainda é a norma prevista no artigo $1678 . .^{\circ} \mathrm{n}^{\circ} 2$ al. a) do Código Civil. Efectivamente, neste caso, a administração e disposição dos proventos que cada cônjuge recebe pelo seu trabalho, embora os bens sejam próprios ou comuns por força do regime de bens que vigora no casamento, cabe a cada um. O que satisfaz a comunidade conjugal, pois deixa à consciência dos interessados a solução para prosseguir com o interesse da família.

\section{A comunidade familiar e os filhos}

A família contemporânea é sobretudo um grupo fechado de pais e filhos (e também de avós). Os filhos saem da "rua" para regressarem a casa; de onde vão saindo os trabalhadores da empresa doméstica, os criados, os dependentes de toda a ordem. Surge o sentimento da casa (lar, "home", "chez soi", etc.) como espaço de convívio íntimo defendido dos outros.

Até ao século XVIII o estreito relacionamento das pessoas não deixava espaço para a individualidade familiar. Todos os acontecimentos familiares - o casamento, o nascimento, a morte, etc. - eram largamente partilhados. 
A família, até ao século XVIII, era também uma organização patrimonial, de poder, de suporte de um estatuto social e, só depois, de sentimento.

A partir do século XIX, a família é, antes de mais, um espaço de sentimentos, portador de valores.

À medida que o homem deixava de estar-no-mundo, passava a estar-na-família. A família substituía o evanescente relacionamento social fundado dos tempos antigos.

A actividade da família deixa de estar centrada na sua perpetuação enquanto organização no tempo; visando aumentar o seu património, o seu estatuto social, o seu poder, à custa do "sacrifício" dos seus membros. A família contemporânea deixa de ser uma organização, para se representar como um conjunto de indivíduos.

Os pais concentram-se no destino dos filhos, já não no destino do grupo - que passa, necessariamente, por cada um dos seus membros. A preocupação educativa surge no centro de cada família que assume decisivamente no século XIX uma função moral e intelectual, formando os espíritos e os intelectos.

Mas esta nova preocupação é contemporânea do início do regresso das crianças à "rua". Com a intensificação da divisão social do trabalho, a transmissão da ciência e das técnicas passa a ser assumida por organizações especializadas, exteriores à família: o mestre particular, o pequeno colégio, a escola pública, a Universidade, etc. E acaba por fugir ao controlo da família que tende a tornar-se simples família-dormitório. Enquanto que a "rua" dos tempos antigos era um espaço dominado pelas famílias - centros de poder, a rua actual é vazia, estando as famílias fechadas em casa.

A sociabilização das crianças é feita na "rua" por organizações não-familiares ou por indivíduos.

A esta evolução tem correspondido idêntica alteração das relações entre pais e filhos, sem destruir a inserção dos filhos na comuni- 
dade familiar, tanto a nível dos sentimentos como no que se refere ao património.

\section{Deveres de pais e filhos}

Os pais e filhos devem-se mutuamente respeito, auxílio e assistência (artigo $1874^{\circ}$ do Código Civil), compreendendo o dever de assistência a obrigação de prestar alimentos e a de contribuir durante a vida em comum, de acordo com os recursos próprios, para os encargos da vida familiar. Estando os filhos sujeitos às responsabilidades parentais até à maioridade ou emancipação (artigo $1877^{\circ}$ do Código Civil).

Acrescente-se a administração pelos pais de parte dos bens dos filhos (artigo $1888^{\circ}$ do Código Civil).

Está aqui definida a estrutura jurídica da comunidade familiar no que se refere às relações pais/filhos.

Sublinhe-se que, se o dever de prestar alimentos, a cargo dos pais e de contribuir, quanto aos filhos, para os encargos da vida familiar, dura em princípio até à maioridade ou emancipação, a relação pais /filhos, deveres de respeito e auxílio, não termina (artigo $1874^{\circ}$ do Código Civil).

Como nos parece não terminar o dever de assistência mútua dentro dos quadros dos valores sociais e das possibilidades de cada um.

\section{O Direito das Sucessões e a comunidade familiar}

Tanto na Germânia como em Roma, o testamento começou por não existir: a propriedade era familiar.

Comparando o direito germânico com o direito romano, pode descobrir-se a razão deste desconhecimento: os germanos não tinham, 
no seu direito, o instituto da "patria potestas", um poder absoluto e unitário, pessoal e patrimonial, concentrado nas mãos do "pater" e com base no qual este podia dispor, por morte, dos bens da família.

Era a unidade familiar a proprietária dos bens; as alterações na composição "interna" dessa unidade não implicavam qualquer fenómeno sucessório, pois a unidade familiar era sempre a família, não eram comproprietários ou titulares de quotas ideais.

Em Roma, foi com a afirmação da "patria potestas" que o património familiar se transformou em património do "pater", e este passou a poder dispor dele também "mortis causa."

É a "propriedade familiar" indo-europeia e germânica que acaba por determinar a sucessão nos quadros do grupo familiar. O "direito" dos parentes próximos esbate-se; já não é um direito "sobre" os bens, mas "aos" bens deixados sem titular por morte.

$\mathrm{O}$ interesse, social e juridicamente relevante, dos familiares mais próximos, levou, no Direito da Alta Idade Média, a limitar o poder de dispor.

Desde logo, o testamento medieval diferençava-se do testamento romano por se limitar a estabelecer a sorte do património - e já não, com a instituição de herdeiro, a criar um sucessor no poder sobre a família.

Enquanto se restringiam, por influência do direito germânico e do cristianismo, de acordo sobre a regra "solus Deus heredem facere potest" os poderes de disposição patrimonial do testador. Por influência do cristianismo, a família, fundada nos laços do sangue, passou a invocar o direito a uma parte importante da herança (ao lado, eventualmente, das partes dos pobres e da Igreja). A figura de filho e de herdeiro passaram a coincidir naturalmente.

Continuando o direito contemporâneo ligado directamente ao direito romano no que se refere à figura de herdeiro, entendido como sucessor universal ("hereditas nibil est quam sucessio in universum ius quod defunctus habuit - Dig. 4, 16, 24). 
Enquanto que o direito germânico transmitia a norma de que "o morto empossa o vivo" ("le mort saisit le vif", em direito francês): os bens seriam adquiridos "ipso iure", sem necessidade de aceitação. Com base na circunstância de que tais bens se mantinham no círculo de parentes próximos, como recordação da comunhão germânica; não haveria uma verdadeira transmissão ou translação dos bens para outrem.

A conciliação entre a tradição germânica da propriedade familiar e a sucessão testamentária romana, levou a separar o património do "de cuius" em duas massas, uma de livre disposição, outra de devolução forçada aos parentes próximos. Estes últimos bens seriam os "bens de avoenga", os herdados dos antepassados, que teriam de ser transmitidos "mortis causa" aos descendentes, enquanto que os bens adquiridos podiam ser objecto de disposição testamentária.

Esta distinção entre bens "vinculados" e os outros, só desapareceu em Portugal com a extinção dos morgadios ${ }^{9}$, em pleno século XIX. E no Reino Unido ainda hoje subsiste, embora com reduzido alcance prático, dada a diminuição dos bens vinculados, com o desaparecimento do regime feudal.

\section{O fundamento do quadro familiar do fenómeno sucessório}

A sucessão legal - legítima ou legitimária - opera-se nos quadros de família: uma certa parte da herança é devolvida necessariamente a familiares mais próximos (descendentes, ascendentes e cônjuge sobrevivo); outra parte é entregue aos familiares mais próximos (os referidos anteriormente, mais os irmãos e os sobrinhos, os adoptados e adoptantes restritamente, e ainda colaterais até ao quarto

9 Manuel de Almeida e Sousa Lobão, Tratado Pratico dos Morgados, Lisboa, 2.* ed., 1814 . 
grau que não sejam irmãos e sobrinhos do autor da sucessão) na falta de disposição do de cuius. A sucessão dos familiares justifica-se pelo facto de a propriedade continuar a ser, ainda hoje, largamente familiar: usufruída (quando não constituída) pelo conjunto dos familiares mais próximos; que têm, assim, uma expectativa e recebê-la por morte do seu titular (formal). Sendo, aliás, os mais idóneos, em princípio, para a administração desses bens.

Porém, os bens que pertencem à comunidade familiar, independentemente do seu titular formal, estão ao serviço de todos e assim deveria continuar a ser depois da morte do de cuius. Assim, a devolução dos bens não deveria ser vista numa perspectiva individualista, de um para o outro, mas sim do "de cuius" a favor da família. O Direito das sucessões português - como o da generalidade dos países europeus - ignora largamente esta necessidade. Embora alguns institutos haja que podem ser utilizados para evitar a divisão do património ${ }^{10}$.

\section{Os avós e outros ascendentes}

Ignora o Direito escrito, quase completamente, a figura dos avós e outros ascendentes na comunidade familiar. Indo contra valores sociais (ainda presentes em Portugal) e uma realidade constante. Haverá que fazer aqui um trabalho muito vasto e importante.

$\mathrm{Na}$ verdade, com o aumento da esperança de vida, os avós e outros ascendentes estão ainda mais presentes do que no passado na comunidade familiar e têm um papel importante a desempenhar no regresso da família "à casa".

10 Campos, Mónica Martinez de "O Trust como instrumento de preservação da propriedade familiar, pp 51-83 in Revista do Instituto dos Advogados de Minas Gerais - $\mathrm{n}^{\circ}$ 19- 2013. 
Não se poderia falar em comunidade familiar sem ter bem presente não apenas as suas diferentes configurações, mas também as relações que mais directamente lhe dão forma e organização: as que se estabelecem entre as gerações. A família é uma comunidade intergeracional e os avós são o seu pilar e o seu motor ${ }^{11}$. "A solidariedade social e familiar intergeracional e a qualidade dos vínculos afetivos, relacionais e comunicacionais entre as gerações, favorecem o sentimento de segurança e de pertença, a saúde e a qualidade de vida individual e familiar, contribuem para a produção de novas relações papéis e representações, reforçam a coesão e integração do grupo, promovem diferentes formas de solidariedade intergeracional" 12 .

Legalmente presume-se que os avós, segundo o artigo 1887.\%/A do Código Civil, concorrem para o equilíbrio e o desenvolvimento da personalidade dos netos, pois "os pais não podem injustificadamente privar os filhos do convívio com os irmãos e ascendentes". $O$ que significa que caberá aos pais, presumindo a lei que esta ligação intergeracional entre avós e netos ${ }^{13}$, ou bisavós e bisnetos, é benéfica para estes últimos, provar o contrário ${ }^{14}$. "É certo que o amor e a criação de laços afectivos não se pode impor por decisão do Tribunal, mas não é menos certo que, sem conhecimento e convívio entre as pessoas, esses sentimentos também não se poderão desen-

11 Não será por acaso que foi determinado o dia 26 de Julho como o dia dos Avós (dia de Santa Ana e São Joaquim, pais de Nossa Senhora e portanto avós de Jesus Cristo).

12 Ramos, Natália, "Relações e solidariedades intergeracionais na família - Dos avós aos netos". Revista Portuguesa de Pedagogia 2005. Ano 39, n 1, pág. 196.

13 Cfr. MARTins, Rosa; Vitor, Paula Távora, "O Direito dos Avós às relações Pessoais com os Netos na Jurisprudência Recente", in Revista Julgar, n. ${ }^{\circ}$ 10, JaneiroAbril 2010.

${ }^{14}$ STJ, 03/03/1998, CJ/STJ de 1998, I, pág. 119 e BMJ 475, 1998, pág. 705. No mesmo sentido dispõe o art. ${ }^{\circ} 9 .^{\circ}$, n. $^{\circ} 3$, da Convenção sobre os Direitos da Criança: "podendo as suas relações pessoais e contactos directos ser com outras pessoas, salvo se tal se mostrar também contrário ao interesse da criança...". 
volver. Há que criar oportunidades e deixar que os relacionamentos sigam o seu destino"15.

O Supremo Tribunal de Justiça, chamado a clarificar a aplicação do artigo 1887.\%/A do Código Civil, proferiu em 1998 um acórdão ${ }^{16}$ onde se lê que "Reconhecendo que as relações com os avós são da maior importância para os netos, ao menos em princípio, quer pela afectividade que recebem, quer pelo desenvolvimento do espírito familiar que proporcionam, o legislador consagrou "um direito de o menor se relacionar" com os avós, que poderá ser designado por "direito de visita". Com este "direito de visita", genericamente entendido como o estabelecimento de relações pessoais entre quem está unido por estreitos laços familiares, pretendeu-se tutelar a ligação de amor, de afecto, de carinho e de solidariedade existente entre os membros mais chegados da família”.

Por outro lado, os avós contribuem decisivamente para a construção da identidade da comunidade familiar e a sua ligação com os netos é determinante na construção e preservação da identidade da família. A nossa identidade vai sendo construída com a ajuda dos que nos rodeiam e cuidam, e os avós são o vector privilegiado das raízes e da história da família. Conhecemos, entendemos, somos e reconhecemos ser com os outros, na comunidade familiar, através do amor e da história. É também através das memórias que o eu é mais intenso e comunga com os outros ${ }^{17}$.

$\mathrm{Na}$ sociedade as pessoas vivem lado a lado, mesmo que separadas na essência, enquanto que na comunidade familiar permanecem unidas apesar de todas as separações.

15 TRL de 01/06/2010, Proc. 5893/06.5TBVFX.L1-7, in www.dgsi.pt e o comentário no "Direito da Família", n. ${ }^{\circ}$ 27, 5. ${ }^{a}$ Bienal de Jurisprudência", pág. 94.

16 STJ, 03-03-1998, BMJ 475, 1998, pág. 705.

17 Para Daniel Sampaio, in A razão dos Avós, $3^{a}$ ed. Lisboa, Caminho 2008, pág. 79: "A transmissão de valores familiares é feita mais por comportamentos do que por palavras: o sentido da passagem transgeracional encontra-se sobretudo em acontecimentos vividos, mais do que em regras prescritas por adultos". 
(Página deixada propositadamente em branco) 